\title{
ANALISIS TERHADAP PERUBAHAN KETENTUAN PENGGUNAAN TENAGA KERJA ASING MELALUI TEORI MASLAHAH MURSALAH
}

\author{
Marzuki Diono \\ Fakultas Syariah UINMaulana Malik Ibrahim Malang \\ Email:marzukidiono7@gmail.com
}

\begin{abstract}
Abolition of speak Indonesian ability for foreign workers (TKA) itcertainly will make Indonesia as a target for foreign workers. That is why the use of foreign workers eligible to be reviewed in the survey maslahah mursalah. This study include into the research that examines the normative principles of law. The results of this study indicate that the regulation changes of foreign workers usage in the Minister of Labor Regulation Number 16 in 2015 about Procedures of Foreign Workers usage reviewed based on the principle of employment is inappropriate with the principles of employment, such as the principle of non-discrimination that is about Indonesian repeal mandatory requirement for foreign workers. While in maslahah mursalah theory, requirements to upload licensing documents through the online system, and the abolition of Indonesian requirements for foreign workers is also not appropriate because of the changes in these terms, makes it easier for foreign workers to work in the territory of Indonesia.
\end{abstract}

Penghapusan kemampuan berbahasa Indonesia bagi Tenaga Kerja Asing (TKA) bisa dipastikan akan menjadikan Indonesia sebagai sasaran bagi TKA. Sebab itulah penggunaan TKA layak untuk dikaji dalam tinjauan maslahah mursalah.Penelitian ini termasuk ke dalam penelitian normatif yang meneliti tentang asas-asas hukum. Hasilpenelitian ini menunjukkan bahwa perubahan ketentuan penggunaan TKA dalam Peraturan Menteri Ketenagakerjaan No. 16 Tahun 2015 tentang Tata Cara Penggunaan TKA ditinjau berdasarkan prinsip ketenagakerjaan belum sesuai dengan prinsip-prinsip ketenagakerjaan, 
sepertiprinsip non diskriminasi yaitu tentangpencabutan syarat wajib Bahasa Indonesia bagi TKA. Sedangkan dalam teori maslahah mursalah, persyaratan untuk mengunggah (upload) dokumen perizinan melalui sistem online dan dihapusnya syarat bahasa Indonesia bagi TKA juga belum sesuai karena dengan perubahan ketentuan tersebut, memudahkan bagi TKA untuk bekerja di dalam wilayah Indonesia.

Keywords: Foreign Labor, Ministerial Regulation, Maslahah Mursalah

\section{Pendahuluan}

Perkembangan globalisasi identik dengan proses liberalisasi ekonomi dunia, menjadikan dunia menjadi satu pasar yang bebas dalam melakukan transaksi jual dan beli. Globalisasi juga menghendaki bebasnya pergerakan tenaga kerja (pree personal movement) yang akan mengisi lapangan kerja melewati batas wilayah territorial negaranya. ${ }^{1}$ Keadaan yang demikian dapat disebut sebagai liberalisasi pasar kerja. ${ }^{2}$

Khusus bagi Tenaga Kerja Asing (selanjutnya disebut TKA) dewasa ini sudah menjadi suatu fenomena yang lumrah karena pada dasarnya juga telah ada sejak dimulainya industrialisasi di muka bumi ini. Penggunaan TKA di Indonesia sendiri terus mengalami perkembangan dan perubahan sesuai zamannya mulai dari zaman kolonial belanda sampai sekarang ini.

Dari dulu sampai sekarang masalah ketenagakerjaan pada dasarnya ada dua, yaitu masalah kesempatan kerja dan masalah kualitas tenaga kerja. Laju pertumbuhan penduduk Indonesia yang tinggi mengakibatkan jumlah angkatan kerja setiap tahunnya semakin meningkat, sedangkan kesempatan kerja yang tersedia belum dapat memenuhi kebutuhan kerja sesuai dengan jumlah pencari kerja yang ada. Hal ini mengakibatkan ketidakseimbangan antara besarnya jumlah penduduk yang membutuhkan pekerjaan dengan kesempatan kerja yang tersedia. Apalagi sekarang ini ditambah dengan banyaknya jumlah tenaga kerja yang mengalami pemutusan hubungan kerja dari perusahaan tempatnya bekerja. Adanya masalah kekurangan kesempatan kerja ini membuat banyak terjadi pengangguran di Indonesia. Secara tidak langsung penggunaan TKA dalam konteks ini juga akan menambah tinggi

1 Agusmidah, Dilematika Hukum Ketenagakerjaan, Tinjauan Politik Hukum, buku II, (Jakarta: PT.Sofmedia, 2011), h. 349.

2 Wacana liberalisasi pasar kerja telah mulai dikemukakan dikawasan ASEAN dan ternyata tidak mudah untuk membuat aturan-aturan pasar kerja tersebut dikawasan ASEAN dikarenakan masing-masing negara membuat peraturan sendiri dan belum ada standarisasi keterampilan kemampuan kerja dikawasan tersebut. Di indonesia sendiri liberalisasi pasar kerja ini ditanggapi pemerintah dengan merevisi UU No. 13 Tahun 2003 yang didalam nya mengatur tentang tenaga kerja asing. Agusmidah, Dilematika Hukum, h. 350 . 
tingkat persaingan memperoleh kerja dan menjadikan masalah pengangguran di negara ini akan menjadi semakin kompleks.

Kekhawatiran juga muncul dari kalangan pekerja/buruh terutama terhadap kualitas sumber daya pekerja yang berdampak pada kesempatan kerja, perlu disadari bahwa pendidikan pekerja Indonesia masih jauh dari keterampilan pendidikan TKA. ${ }^{3}$ Bukan hanya itu saja Tenaga Kerja Asing (TKA) dipermudah untuk bisa bersaing di Indonesia dengan dihapusnya syarat bahasa Indonesia bagi TKA. Sementara rakyat sendiri dibiarkan berjuang melawan kekuatan yang global yang mengancam eksistensi kapitalisme-neoliberalisme yang menyengsarakan.

Pemberlakuan Masyarakat Ekonomi ASEAN (MEA) 2015 yang sudah berlangsung kemaren, bisa dipastikan akan menjadikan Indonesia sebagai sasaran bagi Tenaga Kerja Asing (TKA). Seluruh tingkatan lapangan kerja di Indonesia akan diserbu TKA, termasuk pekerjaan menengah ke bawah, tanpa ada aturan yang memberi proteksi terhadap kesempatan kerja, alih ilmu dan teknologi bagi rakyat kita sendiri.

Kaitannya dengan penggunaan TKA ini, penulis merasa tertarik untuk mengkaji secara terperinci tentang perubahan ketentuan penggunaan TKA ditinjau dari maslahah mursalah.

\section{Pengertian Maslahah Mursalah}

Secara etimologis "maslahah mursalah" terdiri atas dua suku kata yaitu maslahah dan mursalah.maslahah adalah bentuk mufrad dari al-mashalih. ${ }^{4}$ Maslahah berasal dari kata آَصَلَح secara arti kata berarti "baik". Sedangkan kata mursalah yang berarti "terlepas". Bila kata "maslahah" digabungkan dengan "mursalah", maka secara bahasa berarti "kemaslahatan yang terlepas/bebas dari keterangan yang menunjukkan boleh atau tidaknya dilakukan". ${ }^{6}$

Menurut Abdul Wahab Khallaf, maslahah mursalah adalah maslahah di mana syari' (Allah dan Rosul-Nya) tidak mensyariatkan hukum untuk mewujudkan maslahah, juga tidak terdapat dalil yang menunjukkan atas pengakuannya atau pembatalannya. ${ }^{7}$

3 Agusmidah, Dilematika Hukum, h. 151.

4 Rachmat Syafe'i, Ilmu Ushul Fiqh, Cet. IV, (Bandung: CV Pustaka Setia, 1998), h. 117

5 Amir Syarifuddin, Ushul Fiqh, (Jakarta: Logos Wacana Ilmu, 1999), h. 323

6 Amir, Ushul Figh, h. 323

7 Abdul Wahab Khallaf, Ilmu Ushulil Fiqh, terj. Noer Iskandar al-Barsany, Kaidah-kaidah Hukum Islam, (Cet-8, Jakarta: PT. Raja Grafindo Persada, 2002), h. 123. 


\section{Syarat-syarat Maslahah Mursalah}

Menurut Abdul Wahab Khalaf, maslahah mursalah dapat dijadikan sebagai legislasi hukum Islambila memenuhi syarat yang diantaranya adalah: 1. Berupa maslahah yang sebenarnya (secara hakiki) bukan maslahah yang sifatnya dugaan, tetapi yang berdasarkan penelitian, kehati-hatian dan pembahasan mendalam serta benar-benar menarik manfa'at dan menolak kerusakan. 2. Berupa maslahah yang bersifat umum, bukan untuk kepentingan perorangan, tetapi untuk orang banyak. 3. Tidak bertentangan dengan hukum yang telah ditetapkan oleh nash (al- Qur'an dan al-Hadits) serta ijma' ulama. ${ }^{8}$

\section{Pembahasan}

Perubahan Ketentuan Penggunaan TKA dalam Permennaker No. 16 Tahun 2015 tentang Tata Cara Penggunaan TKA jika ditinjau berdasarkan prinsip hukum ketenagakerjaan yang terdapat di dalam Undang-undang Ketenagakerjaan ialah sebagai berikut:

1) Prinsip Perlindungan Tenaga Kerja Sesuai Harkat dan Martabat Kemanusiaan

Beberapa bentuk perlindungan tenaga kerja yang sesuai dengan kehormatan dan martabat manusia dinyatakan dalam beberapa pasal saja pada Peraturan Menteri Ketenagakerjaan No. 16 Tahun 2015 tentang Tata Cara Penggunaan TKA di bawah ini, di antaranya ialah: Kebijakan pengupahan diatur dalam rencana penggunaan TKA pasal 11 ayat 1.Kebijakan memiliki polis asuransi dan jaminan sosial pada pasal 36 ayat 1 poin d dan e.

2) Prinsip Non Diskriminasi

Pengertian dari prinsip non diskriminasi sendiri dalam penjelasan pasal 5 UU Ketenagakerjaan dijelaskan bahwa setiap tenaga kerja mempunyai hak dan kesempatan yang sama untuk memperoleh pekerjaan dan penghidupan yang layak tanpa membedakan jenis kelamin, suku, ras, agama, dan aliran politik sesuai dengan minat dan kemampuan tenaga kerja yang bersangkutan, termasuk perlakuan yang sama terhadap para penyandang cacat.Namun dalam Peraturan Menteri Ketenagakerjaan No. 16 Tahun 2015 tentang Tata Cara Penggunaan TKA ada beberapa pasal yang belum sesuai dengan prinsip non diskriminasi tentang persyaratan TKA salah satunya adalah tentang persyaratan TKA, dimana dalam persyaratan TKA terdapat pencabutan syarat wajib Bahasa Indonesia bagi Tenaga Kerja Asing dalam pasal 36 ayat 1 Peraturan Menteri Ketenagakerjaan No. 16 Tahun 2015 Tentang Tata

8 Khalaf, Ilmu Ushul, h. 125. 
Cara Penggunaan TKA menurut penulis adalah sebuah bentuk diskriminasi kepada para pekerja Indonesia sendiri karena pada hakikatnya para TKA justru lebih dipermudah untuk bisa bekerja diwilayah Indonesia, sementara para tenaga kerja Indonesia dibiarkan berjuang untuk mendapatkan pekerjaan di negaranya sendiri. Karena para pemberi kerja justru akan lebih memilih TKA dibandingkan dengan tenaga kerja asli Indonesia karena pendidikan pekerja Indonesia masih jauh dari keterampilan pendidikan TKA

3) Prinsip Keterpaduan

Prinsip keterpaduan berarti prinsip adanya kesatuan dan koordinasi antara pihak pemerintah pada tingkat pusat dan pihak pemerintah pada tingkat daerah dalam melakukan sebuah pengawasan. Pengawasan dalam hal ini adalah pengawasan terkait penggunaan TKA baik dalam Rencana Penempatan Tenaga Kerja Asing (RPTKA) atau IMTA (Ijin menggunakan Tenaga Kerja Asing). Pengawasan dilakukan oleh pegawai pengawas ketenagakerjaan. Proses pengawasan yang dilakukan oleh disnaker daerah selalu ada koordinasi dengan pusat. Pengawas di daerah mendapatkan pelatihan dan pembinaan oleh Kemenakertrans. Keterpaduan pengawasan bisa dilihat melalui alur pelaporan pengawasan. Bupati atau walikota akan melaporkan hasil pengawasan kepada Gubernur, dan selanjutnya Gubernur akan melaporkan kepada Menteri Tenaga Kerja dan Transmigrasi.'

\section{Perubahan Ketentuan Penggunaan TKA Dalam Peraturan Menteri Ketenagakerjaan No. 16 Tahun 2015 tentang Tata Cara Penggunaan TKA Berdasarkan Teori Maslahah Mursalah}

Maslahah mursalah sebagai metode hukum yang mempertimbangkan adanya kemanfaatan yang mempunyai akses secara umum dan kepentingan tidak terbatas, tidak terikat. Maslahah mursalah dengan kata lain merupakan kepentingan yang diputuskan bebas, namun tetap terikat pada konsep syari'ah yang mendasar, karena syari'ah sendiri ditunjuk untuk memberikan kemanfaatan kepada masyarakat secara umum dan berfungsi untukmemberikan kemanfaatan dan mencegah kemazdaratan (kerusakan).

Mengenai ruang lingkup berlakunya maslahah mursalah dibagi atas tiga bagian yaitu:

Al-maslahah al-daruriyah, (kepentingan-kepentingan yang esensi dalamkehidupan) seperti memelihara agama, memelihara jiwa, akal, keturunan, dan harta.

9 Khoirul Hidayah, Optimalisasi Pengawasan Ketenagakerjaan di Kota Malang. Dejure Jurnal Fakultas Syariah UIN Maulana Malik Ibrahim. Vol. 7 No. 2 , 2015, hlm. 101-115. 
Al-maslahah al-hajjizah, (kepentingan-kepentingan esensial dibawahderajatnya al-maslahah daruriyyah), namun diperlukan dalam kehidupanmanusia agar tidak mengalami kesukaran dan kesempitan yang jika tidakterpenuhi akan mengakibatkan kerusakan dalam kehidupan, hanya saja akanmengakibatkan kesempitan dan kesukaran baginya.

Al-maslahah al-tahsiniyah, (kepentingan-kepentingan pelengkap) yang jikatidak terpenuhi maka tidak akan mengakibatkan kesempitan dalamkehidupannya, sebab ia tidak begitu membutuhkannya, hanya sebagaipelengkap atau hiasan hidupnya. ${ }^{10}$

Untuk menjaga kemurnian metode maslahah mursalah sebagai landasan hukum Islam, maka harus mempunyai dua dimensi penting, yaitu sisi pertama, harus tunduk dan sesuai dengan apa yang terkandung dalam nash (al-Qur'an dan alHadits) baik secara tekstual atau kontekstual. Sisi kedua, harus mempertimbangkan adanya kebutuhan manusia yang selalu berkembang sesuai zamannya. Kedua sisi ini harus menjadi pertimbangan yang secara cermat dalam pembentukan hukum Islam, karena bila dua sisi di atas tidak berlaku secara seimbang, maka dalam hasil istinbath hukumnya akan menjadi sangat kaku disatu sisi dan terlalu mengikuti hawa nafsu disisi lain, sehingga dalam hal ini perlu adanya syarat dan standar yang benar dalam menggunakan maslahah mursalah baik secara metodologi atau aplikasinya.

Pemerintah Indonesia di tahun 2015 kemaren ini, tampaknya semakin mempermudah persyaratan-persyaratan yang harus dipenuhi untuk dapat mempekerjakan tenaga kerja asing (TKA), diantaranya persyaratan untuk mengunggah (upload) dokumen perizinan baik tentang RPTKA maupun IMTA melalui sistem online dan dihapusnya syarat bahasa Indonesia bagi TKA. Padahal tenaga kerja asing di Indonesia jumlahnya sudah mencapai 70.000 orang TKA.

Persyaratan untuk mengunggah (upload) dokumen perizinan melalui sistem online $^{I l}$ ini secara prosedural maupun subtansinya tentu saja memudahkan karena pengajuan perizinan hanya perlu dilakukan secara online di Badan Kordinasi Penanaman Modal (BKPM), sehingga tidak lagi perlu untuk mengunjungi kementerian/ instansi lainnya untuk pengurusan dokumen pendukung perizinan.

Kebijakan pada pasal 36 ayat (1) Peraturan Menteri Ketenagakerjaan No. 16 Tahun 2015 tentang Tata Cara Penggunaan TKA tentang dihapusnya

10 Muhammad Abu Zahrah, Ushul al-Fiqh, terj. Saefullah Ma'shum, et. al., Ushul al-Fiqh, Cet. 9 (Jakarta: Pustaka Firdaus, 2005), h. 426.

11 Coba lihat dalam pasal pasal 6 ayat 1 tentang RPTKA dan pasal 38 ayat 1 tentang IMTA dalam Peraturan Menteri Ketenagakerjaan No. 16 Tahun 2015 tentang Tata Cara Penggunaan TKA 
syarat bahasa Indonesia bagi TKA ${ }^{12}$, hal ini menjadi pro dan kontra di kalangan masyarakat. Menurut penulis, hal tersebut jelas melenceng dari UU No. 24 Tahun 2009 tentang Penggunaan Bahasa Indonesia, pada Pasal 25 ayat (2) dan pasal 33 ayat (1) bahwasanya Bahasa Indonesia sebagai jati diri bangsa Indonesia, dan bahasa Indonesia wajib digunakan dalam lingkungan kerja pemerintahan dan swasta, meskipun alasan pencabutan bahasa Indonesia bagi TKA adalah untuk peningkatan investasi dan menggenjot ekonomi di Indonesia.

Pemerintah dalam rangka pengendalian jumlah tenaga kerja asing, setidaknya mempertimbangkan beberapa aspek, antara lain soal asas manfaat, yakni apakah penggunaan tenaga kerja asing mendorong pembukaan lapangan kerja yang luas terutama bagi pekerja lokal. Aspek legalitas dan kebutuhan juga menjadi pertimbangan utama bagi keberadaan pekerja dari luar negeri. Pertimbangan lain menyangkut pengembangan SDM, dalam arti apakah masuknya tenaga kerja asing itu akan memberikan kemajuan bagi pengembangan kualitas SDM lokal. Misalnya, menyangkut alih-keterampilan dan alih-teknologi.

Secara garis besar juga, penggunaan tenaga kerja yang paling diprioritaskan pertama kali adalah tenaga kerja warga negara Indonesia untuk tujuan investasi dalam negeri dibandingkan dengan TKA yang mana hal tersebut tertuang dalam Pasal 10 ayat (1) Undang-Undang No. 25 Tahun 2007 tentang Penanaman Modal, menjelaskan bahwa: "Perusahaan penanaman modal dalam memenuhi kebutuhan tenaga kerja harus mengutamakan tenaga kerja warga Negara Indonesia"13

Berbicara tentang tenaga kerja asing, maka sesungguhnya Allah memerintahkan kepada hamba-hambanya untuk mencari rezeki baik di daerahnya maupun ke daerah/negara lain dan keseluruh penjuru dunia, sebagaimana dalam firmanNya yang termaktub dalam Surat Al-Jumu'ah ayat 10 yang berbunyi:

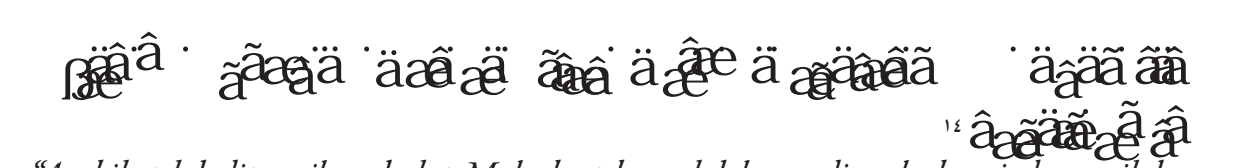

"Apabila telah ditunaikan shalat, Maka bertebaranlah kamu di muka bumi; dancarilah karunia Allah dan ingatlah Allah banyak-banyak supaya kamu beruntung."

Tenaga kerja asing merupakan bagian hubungan ekonomi Internasional,

12 Pasal 36 ayat 1 Peraturan Menteri Ketenagakerjaan No. 16 Tahun 2015 tentang Tata Cara Penggunaan TKA

13 Pasal 10 ayat (1) Undang-undang Republik Indonesia No. 25 tahun 2007 tentang Penanaman Modal.

14 QS. Al-Jumu'ah (62) : 10 
Jaribah bin Ahmad al-Haritsi pengarang buku Fikih ekonomi Umar bin al-Khatab mengatakan, bahwa agar hubungan ekonomi Internasional dapat merealisasikan kemanfaatan sebesar mungkin bagi kaum muslimin dan menjauhkan mereka dari mudharat yang akan terjadi, maka hubungan tersebut harus memenuhi kaidahkaidah sebagai berikut: Pertama, Kehalalan barang dan jasa di tempat perdagangan; Kedua, Jika hubungan ekonomi internasional dapat merealisasikan kemaslahatan bagi kaum muslimin; Ketiga, Jika wilayah-wilayah Islam sebagai prioritas; Keempat, Pengaturan masuk dan menetapnya non muslim di bumi Islam; yaitu 1) Larangan masuknya non-muslim ke sebagian daerah kecuali disebabkan kebutuhan kaum muslimin 2) Pembatasan masa menetap 3) Tidak boleh menampakkan kemungkaran 4) Pengusiran orangyang melanggar persyaratan 4) Menghindari pemberian mereka dalam sebagian pekerjaan; Kelima, Perjanjian perdagangan; Keenam, Negara Islam seyogyanya memiliki otoritas dalam pengaturan dan pengawasan hubungan ekonomi luar negeri; Ketujuh, Urusan kegiatan ekonomi harus dipimpin seorang Muslim jika terdapat non-Muslim yang andil di dalamnya. ${ }^{15}$

Tenaga kerja asing di Indonesia belum bisa masuk dalam kategori maslahah mursalah, alasannya karena pada prinsipnya ketentuan pasal-pasal pada Peraturan Menteri Ketenagakerjaan No. 16 Tahun 2015 di atas adalah untuk membawa kemudzaratan. Pasal 36 sangat tampak unsur untuk menimbulkan ke mudzaratan bagi pekerja asli Indonesia, karena TKA di Indonesia lebih dipermudah untuk bisa bekerja di dalam wilayah Indonesia dengan dihapusnya syarat bahasa Indonesia bagi TKA.

Penggunaan TKA di Indonesia bila ditinjau dari segi maslahah mursalah memang ada maslahah dan mafsadahnya. Dari segi maslahabnya TKA unggul dalam hal penguasaan teknologi karena hal tersebut bisa menunjang perusahaan dalam mengembangkan bisnisnya, namun di lain pihak ada mafsadah yang muncul yakni para pekerja warga Negara Indonesia banyak yang mengalami pengangguran karena harus bersaing dengan para TKA dengan adannya Masyarakat Ekonomi Asean (MEA) ini.

Dari segi syarat, dapat dilihat maslahah mursalah tentang penggunaan TKA ini, ada poin yang memang tidak terpenuhi disini, karena pada hakikatnya Maslahah mursalah dapat dijadikan sebagai legislasi hukum Islam bila memenuhi syarat yang diantaranya adalah:

1. Berupa maslahah yang sebenarnya (secara hakiki) bukan maslahah yang sifatnya dugaan, tetapi yang berdasarkan penelitian, kehati-hatian dan pembahasan mendalam serta benar-benar menarik manfa'at dan menolak

15 Jaribah bin Ahmad al-Haritsi, Fikih Ekonomi Umar bin Al-khathab, Terj. Asmuni Sholihan Zamakhsyari, (Cet. I, Jakarta: Khalifa, 2006), h. 547 
kerusakan.

2. Berupa maslahah yang bersifat umum, bukan untuk kepentingan perorangan, tetapi untuk orang banyak.

3. Tidak bertentangan dengan hukum yang telah ditetapkan oleh nash (alQur'an dan al-Hadits) serta ijma' ulama. ${ }^{16}$

Syarat-syarat maslahah tersebut, disebutkan bahwa maslahah tersebut adalah maslahah yang bersifat umum, bukan untuk kepentingan perorangan, tetapi untuk orang banyak. Penggunaan TKA sendiri hanya untuk kepentingan perusahaanperusahaan milik perorangan atau badan hukum saja, tidak membawa manfaat bagi masyarakat secara menyeluruh, oleh karena itulah penggunaan TKA itu tidak bisa dilihat dari segi maslahah mursalah, di samping dia hanya membawa maslahah hanya untuk kepentingan pribadi juga menimbulkan pekerja asli warga Negara Indonesia banyak yang mengalami pengangguran bahkan di PHK di negerinya sendiri. Untuk itulah penggunaan TKA di Indonesia akan banyak mafsadah yang ditimbulkan karenanya maka alangkah baiknya mafsadah yang akan timbul nantinya bisa didahulukan, dibandingkan dengan menarik kemaslahatannya, hal ini sesuai dengan kaidah:

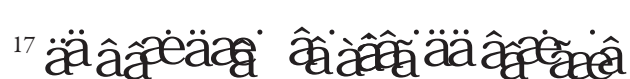

Artinya: "Menolak segala yang rusak lebih didabulukan atas menarik segala yang bermaslahah".

Mengenai ruang lingkup maslahah mursalah yaitu maslahah dharuriyah, adalah hifdz nasl (menjaga keturunan). Menjaga keturunan adalah merupakan harta yang pokok dalam kehidupan dan merupakan sebab memakmurkan bumi, karena dalam keturunan itu terpendam kekuatan umat. Menjaga keturunan mempunyai arti menjaga keberlangsungan generasi masa depan. Upaya menjaga kesinambungan generasi manùsia antara lain disebutkan dalam QS. al-Nisâ': 9.

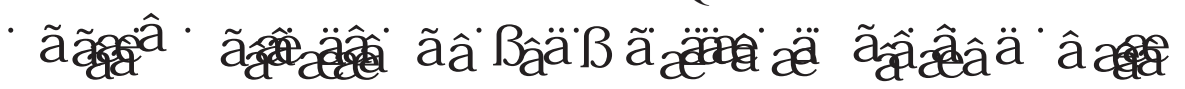

Artinya: "Dan hendaklah takut kepada Allah orang-orang yang seandainya meninggalkan dibelakang mereka anak-anak yang lemah, yang mereka khawatir terhadap (kesejabteraan) mereka. oleh sebab itu hendaklah mereka bertakwa kepada Allah dan hendaklah mereka mengucapkan Perkataan yang benar".

16 Khalaf, Ilmu Ushul, h. 125.

17 Jalaluddin al-Suyuti, Al-Asbah wa al-Nazdo'ir, )Semarang: Maktabah Usaha Keluarga, 1987(, h. 31

18 QS. al-Nisâ' (4): 9. 
Berkaitan dengan tenaga kerja, harus ada regulasi nasional yang mendukung, menguntungkan, menguatkan serta meningkatkan daya saing dan sumber daya para pekerja Indonesia, karena mereka adalah kekuatan ekonomi bangsa dan negara. Apabila segala lapangan pekerja dipenuhi oleh tenaga kerja asing, maka akan berakibat banyaknya tenaga kerja Indonesia yang menjadi pengangguran. Dampaknya akan berakibat rusaknya dan terputusnya generasi bangsa Indonesia. Untuk itu ide penghapusan kewajiban berbahasa bahasa Indonesia bagi tenaga kerja asing adalah suatu hal yang bertentangan dengan maslahah dharuriyah, yaitu menjaga keturunan.

\section{Simpulan}

Berdasarkan pembahasan yang telah diuraikan di atas, maka dapat diambil kesimpulan sebagai berikut:

1. Dalam perubahan ketentuan Penggunaan TKA Dalam Peraturan Menteri Ketenagakerjaan No. 16 Tahun 2015 tentang Tata Cara Penggunaan TKA ditinjau berdasarkan prinsip ketenagakerjaan dalam UU No. 13 Tahun 2003 tentang Ketenagakerjaan belum sepenuhnya sesuai dengan prinsip-prinsip ketenagakerjaan salah satunya dalam Prinsip Non Diskriminasi yaitu tentang pencabutan syarat wajib Bahasa Indonesia bagi TKA dalam pasal 36 ayat 1 Peraturan Menteri Ketenagakerjaan No. 16 Tahun 2015 Tentang Tata Cara Penggunaan TKA, dimana pencabutan syarat wajib Bahasa Indonesia bagi TKA menurut penulis adalah sebuah bentuk diskriminasi kepada para pekerja Indonesia sendiri karena pada hakikatnya para TKA justru lebih dipermudah untuk bisa bekerja diwilayah Indonesia, sementara para tenaga kerja Indonesia dibiarkan berjuang untuk mendapatkan pekerjaan di negaranya sendiri. Karena para pemberi kerja justru akan lebih memilih TKA dibandingkan dengan tenaga kerja asli Indonesia karena pendidikan pekerja Indonesia masih jauh dari keterampilan pendidikan TKA.

2. Dalam perubahan ketentuan penggunaan TKA dalam Peraturan Menteri Ketenagakerjaan No. 16 Tahun 2015 tentang Tata Cara Penggunaan TKA berdasarkan teori maslahah mursalah juga belum sesuai dengan teori maslahah mursalah karena belum memenuhi syarat-syarat maslahah mursalah sendiri, di dalam persyaratan maslahah mursalah disebutkan bahwa maslahah tersebut adalah maslahah yang bersifat umum, bukan untuk kepentingan perorangan, tetapi untuk orang banyak. Sedangkan penggunaan TKA sendiri hanya untuk kepentingan perusahaan-perusahaan milik perorangan atau badan hukum saja, tidak membawa manfaat bagi masyarakat secara menyeluruh 
oleh karena itulah penggunaan TKA itu tidak bisa dilihat dari segi maslahah mursalah, di samping dia hanya membawa maslahah hanya untuk kepentingan pribadi juga menimbulkan pekerja asli warga Negara Indonesia banyak yang mengalami pengangguran bahkan di PHK di negerinya sendiri apalagi dengan penghapusan syarat berbahasa Indonesia bagi TKA. Karena itulah penggunaan TKA di Indonesia akan banyak mafsadah yang ditimbulkan karenanya, maka alangkah baiknya mafsadah yang akan timbul nantinya bisa didahulukan, dibandingkan dengan menarik kemaslahatannya.

\section{Daftar Pustaka}

Al-Qur'an

Abu Zahrah, Muhammad, 2005, Ushul al-Figh, terj. Saefullah Ma’shum, et. al., Ushul al-Figh, Cet. 9, Jakarta: Pustaka Firdaus, 2005.

Agusmidah, Dilematika Hukum Ketenagakerjaan, Tinjauan Politik Hukum, buku II, Jakarta: PT.Sofmedia, 2011.

Al-Haritsi, Jaribah bin Ahmad, Fikih Ekonomi Umar bin Al-khathab, Terj. Asmuni Sholihan Zamakhsyari, Cet. I, Jakarta: Khalifa, 2006.

Al-Suyuti, Jalaluddin, Al-Asbah wa al-Nazdoir, Semarang: Maktabah Usaha Keluarga, 1987.

Hidayah, Khoirul. Optimalisasi Pengawasan Ketenagakerjaan di Kota Malang. Dejure. Vol. 7 No. 2, 2015

Khallaf, Abdul Wahab, Ilmu Ushulil Figh, terj. Noer Iskandar al-Barsany, Kaidahkaidah Hukum Islam, Cet-8, Jakarta: PT. Raja Grafindo Persada, 2002.

Marzuki, Peter Mahmud, Penelitian Hukum, Cet.VI, Jakarta: Kencana, 2010

Syafe'I, Rachmat, Ilmu Ushul Figh, Cet. IV, Bandung: CV Pustaka Setia, 1998.

Syarifuddin, Amir, Ushul Fiqh, Jakarta: Logos Wacana Ilmu, 1999.

\section{Peraturan Perundang-Undangan}

Undang-undang No. 13 Tahun 2003 Tentang Ketenagakerjaan

Undang-undang Republik Indonesia No. 25 tahun 2007 tentang Penanaman Modal.

Peraturan Menteri Ketenagakerjaan No. 16 Tahun 2015 tentang Tata Cara Penggunaan TKA. 